\title{
PSYCHE
}

VOL. XLIII

DECEMBER, 1936

No. 4

\section{NEW SPECIES OF SOUTHERN SPIDERS}

By Elizabeth B. BRyant

Museum of Comparative Zoölogy

Cambridge, Mass.

During the winter and spring of 1935 a student at Southern Methodist University collected spiders throughout Dallas County, Texas. It is a section of the country from which little is known of the spider fauna. Among them were five new species and the male of a species known only from the type from Okefenokee Swamp, Georgia. From a small collection from Florida two species were found to be new and from the Florida Keys was found a male of a $\mathrm{Cu}-$ ban species known only from the female. Many species of spiders have been found to be common to Florida and Texas.

\section{OECOBIIDAE}

Oecobius texanus sp. nov.

Fig. 8, a, b, c, d, e

Female. Length, $2.5 \mathrm{~mm}$.; ceph., $0.7 \mathrm{~mm}$.; abd., $1.6 \mathrm{~mm}$.; width of ceph. $0.8 \mathrm{~mm}$.

Cephalothorax yellowish white with a dark margin and median area from eyes to posterior margin shaded with dark gray, black about eyes, broader than long, thoracic groove long and lightly impressed, clypeus protruding and shaded with gray; eyes closely grouped on a distinct elevation which falls away on all sides, anterior row procurved, a.m.e. largest of eight, round and dark, separated by more than a diameter and almost touching a.l.e. which are half 
the size, flat and white, posterior row about the same length, strongly procurved, p.l.e. little smaller than a.m.e., round and dark and almost touching a.m.e., p.m.e. flat, white and triangular, separated by their long diameter; quadrangle of median eyes slightly wider in front and as high as wide; clypeus protruding and longer than quadrangle with a few
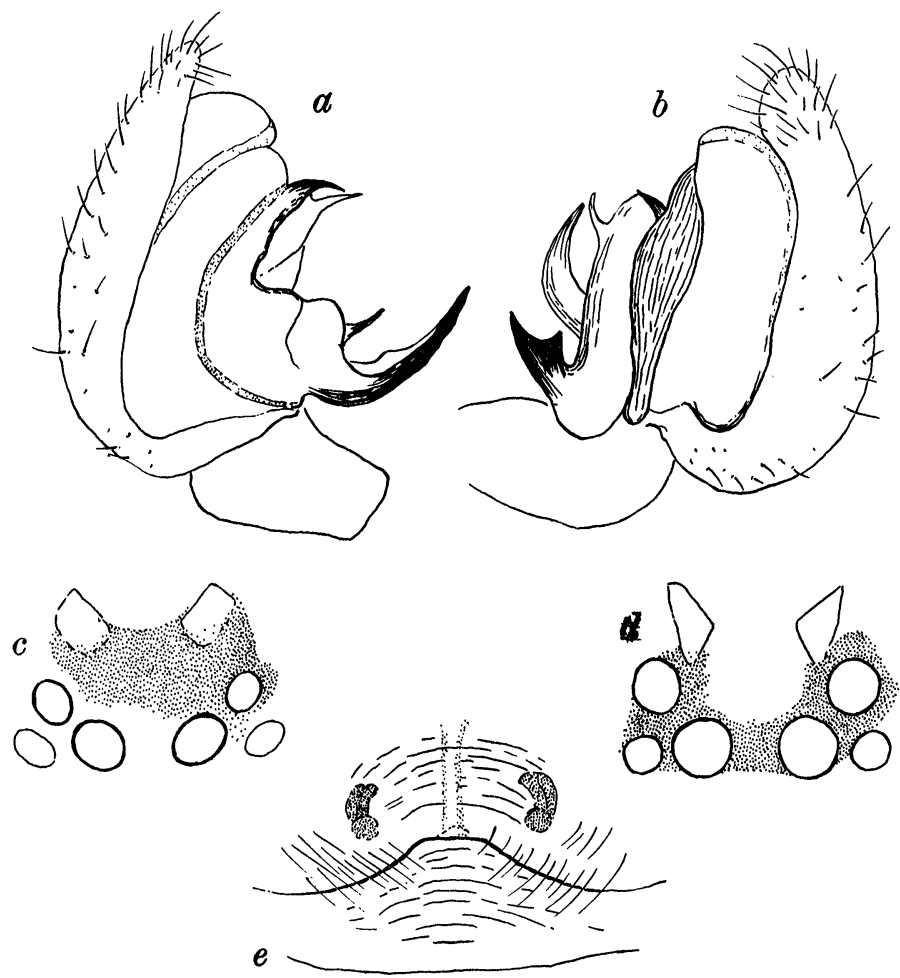

Fig. 1. a, and b, left palpus; c, eyes (male); $d$, eyes (female); e, epigynum.

colorless hairs at margin and a pair of very long hairs projecting forward directly above a.m.e.; mandibles colorless, weak and covered with long hairs, many with globular tips, fang impossible to see; labium triangular, as high as wide at base; maxillæ pale with many hairs, curved and almost 
surrounding labium, pedipalps colorless, long and parallel, extending forward with a single claw; sternum colorless, wider than long, margins with many short hairs; abdomen oval, two thirds as wide as long, base slightly bilobed, a dull tan thickly covered with irregular chalky white spots, entire abdomen sparsely covered with very long colorless hairs, venter paler with the same chalky white spots; legs colorless with no indication of dark rings, hairy with many bristles that can hardly be called spines, I and II femora with a double row of heavy bristles, calamistrum double, extending over little more than the basal half of IV metatarsus; spinnerets protruding, of the usual type; epigynum with a bilobed chitinized margin thinly fringed with long colorless hairs above a slightly darkened area with transverse wrinkles; above the chitinized margin are two widely separated darkened areas.

Male. Length, $2.0 \mathrm{~mm}$; ceph., $0.8 \mathrm{~mm}$.; abd., $1.3 \mathrm{~mm}$.; width of the cephalothorax $1.0 \mathrm{~mm}$.

Cephalothorax, pale as in female but without the dark margin, eye elevation higher than in female so that clypeus is almost vertical; palpus long, femora parallel, patella and tibia about equal length, terminal joint brown and palpal organ dark brown, projecting from cymbium quite the length of the joint as figured.

Holotype of Texas; Dallas, 17 March, 1935, (S. Jones). Allotype $\&$ Texas; Dallas, 28 March, 1935, (S. Jones). Paratype of Texas; Dallas, 14 June, 1935, (S. Jones). Paratype $\&$ Texas; Dallas, 13 May, 1935, (S. Jones).

This genus has been represented in the United States by Oecobius parietalis (Hentz) found in the southern states. Chamberlin and Ivie have made a revision of the American species of the family in Ann. Ent. Soc. Amer., 1935, 28, pp. 262-272, pls, 1-4. They have described a new species Oecobius isolatus from immature females found at Carmen Island, Gulf of California and Sycamore Creek, Arizona. This species has heavily annulated legs and a carapace blackish. The relative position of the eyes is not given.

As so many small spiders are carried by commerce, it was thought that there was a possibility that this species might be Oecobius maculatus Simon, the species found about 
the Mediterranean. As there were no specimens of this species in the museum collection, drawings of the Texan species were sent to the Paris Museum and M. Berland kindly compared them with the two European species. It was found to be different from either.

\section{AGELENIDAE}

Tegenaria simplex sp. nov.

Fig. 9

Female. Length, ceph., $2.2 \mathrm{~mm}$.; abd., $3.1 \mathrm{~mm}$.

Cephalothorax light yellowish brown, cephalic portion high, outlined with a broad stripe of dusky gray which continues to the posterior margin, lateral margins with a narrow black line and fringed with long dark hairs directed forward, thoracic groove long; eyes cover little more than middle half of the head, anterior row slightly procurved, eyes equidistant, a.m.e. smallest of the eight, separated by less than a radius, posterior row little longer than anterior, eyes equidistant, p.m.e. largest of the eight, separated by a diameter, lateral eyes almost touching and subequal; quadrangle of median eyes narrower in front and higher than wide; clypeus more than a diameter of a.m.e.; mandibles vertical, long, front surface flat with many black bristles, fang groove oblique, superior margin with scopula of long hairs, four distinct teeth, inferior margin with four teeth, fang long; labium as high as wide, tip rebordered, lateral margins almost parallel and excavate at basal fourth; maxillæ twice as long as labium with sides parallel; sternum with broad lateral dark stripes broken by two pairs of light spots opposite I and II coxæ, as wide as long, sides almost parallel between I, II and III coxæ, tip continued in a slender point between IV coxæ; abdomen two-thirds as wide as long, pale yellow with the usual grayish marks, tip much darker, venter pale with a gray rectangle from fold to spinnerets, containing two pale poorly defined parallel stripes; spinnerets, superior pair with long basal joint, terminal joint about two-thirds as long, inferior pair shorter than basal joint of superior; legs long and slender, IV pair missing, pale, femora darker with faint gray rings; 
epigynum dark reddish-brown, with margins heavily chitinized, openings small and round, widely separated leading by spiral tubes to sacs above.

Holotype $\&$ Texas; Dallas, near Southern Methodist University, 5 April, 1935.

This species is marked like Tegenaria cavicola Banks, from Salt Petre Cave, Indiana. Unfortunately the type of this species is immature. The posterior row of eyes is not as strongly procurved as in Tegenaria domestica but the epigynum has the same broad lobe. It differs from Tegenaria obscura Banks, described from a single female by the different proportion in length of the joints of the spinnerets and position of eyes of posterior row.

\section{LYCOSIDAE}

Schizocosa perplexa sp. nov.

Fig. 2

Male. Length, $9.0 \mathrm{~mm}$; ceph., $5.0 \mathrm{~mm}$; abd., $4.0 \mathrm{~mm}$.

Cephalothorax with light stripe from second eye row to posterior margin, with sides evenly converging from the posterior eyes so that width at posterior margin less than half the greatest width, covered with short white hairs, sides brown, thickly covered with short black hairs, no indications of submarginal light stripe, very dark about eyes; eyes anterior row shorter than second row, a.m.e. separated by little over a radius, larger than a.l.e. and separated from them by less than a radius, eyes of second row separated by about a diameter; mandibles dark brown, covered with long black hairs, vertical, superior margin of fang groove with three teeth, middle largest, inferior margin with three subequal teeth; labium higher than wide, lateral excavations at base about one third the length; maxillæ twice as high as labium; sternum and coxæ light; abdomen with light brown basal stripe which disappears about middle; in this the usual spear-mark can be traced outlined by black dots, sides black, entire abdomen thickly covered with long dark hairs and a few longer white hairs at base on light stripe; venter dark with a few scattered lighter spots and a narrow, median light stripe from fold to spinnerets; legs, I 
left, II right missing, I leg darkest, others same color as light stripe of cephalothorax, I tibia thickly covered with short erect black hairs, metatarsus with dark hairs not as numerous, these black hairs not as long as diameter of joint and much shorter than in Schizocosa ocreata (Hentz), spines, I tibia, dorsal 0 , ventral, 2-2-2, basal and median pairs not overlapping, 1 lateral, metatarsus, 2-2, 1 lateral, posterior pairs spiny, III and IV tibiæ with dorsal basal and median spines; palpus, same color as legs, not as long as cephalothorax, seen from above, patella little longer than tibia, tibia only slightly swollen, not as broad as long, a small dark dorsal cusp extending towards cymbium, palpal organ lacking horn, principal tenaculum about the middle, unequally bidentate, lesser tenaculum situated above the middle, bent at right angles and turned downwards, above and parallel with the distal half is another slightly smaller process.

Holotype $\hat{o}$, Texas; Dallas, Garland Swimming Pool, 25 March 1935 (S. Jones).

This species is a little larger than Schizocosa puebla Chamb. from Albuquerque, New Mexico, and is easily separated by the darker first leg, and tibia of the palpus shorter than patella and very different palpus.

\section{OXYOPIDAE}

\section{Oxyopes helius Chamberlin}

Fig. 7

Ent. News, 1929, 40, p. 19, fig. 4.

Male. Length, $4.0 \mathrm{~mm}$; ceph., $2.0 \mathrm{~mm}$.; abd., $4.0 \mathrm{~mm}$.

Cephalothorax with median light stripe starting from p.l.e., constricted to half that width at thoracic groove, suddenly widening and narrowed at posterior margin to same width as thoracic groove, dark lateral stripes about the same width as median light stripe with irregular margins on each side and extending below eyes on clypeus, sides light yellow with patches of white scales, thoracic groove long and faintly impressed; eyes, anterior row strongly recurved, a.m.e. smallest of eight, separated by a little more than a diameter and from a.l.e. by a diameter, a.l.e. 
separated by almost two diameters and subequal with eyes of posterior row, slightly nearer a.m.e. than to p.l.e., posterior row of eyes strongly procurved, longer than anterior row, subequal and equidistant; quadrangle of median eyes much narrower in front, quadrangle of a.l.e. and p.m.e. of same width in front as behind and slightly wider than high; clypeus, very dark, showing no trace of vertical lines, three quarters as high as quadrangle of median eyes; mandibles small and dark, front surface light brown with a broad dark blotch, fang and fang groove short; sternum triangular, light yellow, margins heavily shaded in dark gray; coxæ light with dark margins; abdomen dark with no definite pattern, venter very dark; legs, without the dark longitudinal lines found in O. salticus, femora and tibiæ shaded with gray, very dark in ventral surface; palpus very dark, cymbium thickly covered with short black hairs and without the conspicuous conical dorsal prominence found in $O$. salticus; patella seen from above longer than tibia, as long as broad with several strong, dark apophyses on ventral side and a hammer shaped light lateral apophysis, tibia with a single enlargement at tip on ventral side which probably interlocks with a process on the patella; palpal organ of the usual type and completely filling the cavity.

Allotype o Texas; Kaufman, 3 miles E. of Parson's Slough, 13 May 1935, (S. Jones).

The holotype was described from a female from Okefenokee Swamp, Georgia. Both male and female were taken at Parson's Slough, Texas. The male differs from any species found in North America and Mexico by the processes on the patella, as all known species have the processes on the tibia and patella smooth. Simon states that $O$. lepidus Blackw. (similaris Stol.) has a process on the patella.

\section{DRASSIDAE}

Nodocion agilis sp. nov.

Fig. 3

Male. Length, $5.0 \mathrm{~mm}$; ceph., $2.5 \mathrm{~mm}$; abd., $2.8 \mathrm{~mm}$.

Cephalothorax, a golden brown, smooth and shining with 
a few hairs on posterior half, low, much narrowed in front, sides evenly rounded, thoracic groove short but distinct, radical striæ indistinct; eyes closely grouped covering two thirds of the head, anterior row weakly procurved, a.m.e. smallest of eight, separated by a little less than diameter and almost touching the flat and much larger a.l.e., posterior row same length as anterior, slightly procurved, p.m.e. angular, about the same size as p.l.e., separated by less than short diameter and from p.l.e. by even less, p.l.e. slightly smaller than a.l.e. and separated from them by less than diameter of the latter; quadrangle of median eyes narrower behind and higher than wide; clypeus little wider than diameter of a.m.e.; mandibles brown, vertical, median half thickly covered with short black bristles directed inward so as to form a thick brush, fang groove short, no teeth on either margin, fang weak; labium, narrower than high, sides almost parallel, palpi inserted beyond the middle of the maxillæ, tips inclined over labium; sternum bright yellow with a few stiff black bristles about the margin, three-quarters as wide as long, IV coxæ separated by less than half a diameter, I coxæ longer than IV, all coxæ can be seen from dorsal side beyond cephalothorax; abdomen a dull gray thickly covered with short stiff hairs, longer at base, venter lighter, inferior spinnerets separated by more than a diameter; legs, IV right leg missing, I leg longest, femur enlarged and flattened laterally; spines, I and II, femur, 1-1, dorsal, patella, tibia and metatarsus, 0 , III and IV, femur, 1-1 dorsal, patella, tibia, dorsal O, several lateral and ventral not in pairs; palpus about as long as cephalothorax, febur longer than patella + tibia, tibia two-thirds as long as patella, tibial spur almost as long as joint, longer than diameter, pressed close to cymbium two thirds length and then bent outward, tip truncate, palpal organ completely filling cavity, embolus arising from near the tip making a sharp turn backwards and ending in a slender tip on the cymbium, on the opposite margin about the middle is a short black spur or spine parallel to the plane of the cavity.

Holotype of Texas; Dallas, house on Oak Cliff, 15 May, 1935, (S. Jones). 
The genus was based on a female from California. Chamberlin described one male that has a similar palpal organ but differs from the Texas species by the proportion of the joints of the palpus and the much longer tibial spur.

\section{Drassyllus pullus sp. nov.}

Fig. 4, 5

Male. Length, $5.1 \mathrm{~mm}$; ceph., $2.2 \mathrm{~mm}$.; abd., $3.0 \mathrm{~mm}$.

Cephalothorax dark brown with no light area, thoracic groove short but distinct, sides evenly rounded, front margin about same width as posterior; eyes covering middle half of head, anterior row straight, a.m.e. smallest of eight, separated by less than a diameter and from a.l.e. by less than a radius, a.l.e. largest of eight, posterior row a little longer than anterior row, straight, p.m.e. little smaller than a.l.e. round, separated by a diameter and from p.l.e. by less; quadrangle of median eyes slightly narrower in front and higher than wide; clypeus less than diameter of a.m.e.; mandibles dark brown, vertical, median margin covered with long bristles, fang groove slightly oblique, superior margin with numerous stiff bristles and two subequal teeth, inferior margin with three small teeth, fang stout at base and evenly curved; labium higher than wide, lateral margin excavate at basal third then sides slightly inclined towards tip; maxillæ once and a half times as high as labium; palpi inserted very near the tip; maxillæ distinctly impressed; sternum brown, two-thirds as wide as long, ending in a blunt point in front of IV coxæ, sides with numerous long bristles; abdomen oval, a dark gray, thinly covered with long hairs, basal scutum very distinct extending one third length of abdomen, venter pale, with a scutum separate from dorsal and extending from pedicle to fold; inferior spinnerets separated by more than a diameter; legs, I pair, and II right missing, dark with many long hairs and bristles, spines, II tibia, O spines ventral or lateral, metatarsus, 2 basal, rather weak, IV tibia, O spines dorsal but a lateral pair; palpus not as long as cephalothorax, seen from above patella longer than tibia, tibia 
longer than wide, tibial apophysis longer than joint and extends one half length of cymbium, slender and smooth, embolus, short, starting from near the tip, making an abrupt turn soon after its origin, on opposite side of tip a slender black spine which extends slightly outside on cymbium, seen from the side between the embolus and the black spine are two leaf-like pieces with dark margins which cover the parts at the tip like a veil; at base of the organ is a dark round knob.

Holotype 1 ô Florida; Coral Gables, 17 June, 1935 (O. C. Webb).

\section{Herpyllus faxoni sp. nov.}

Fig. 6

Female. Length, exclusive of spinnerets, $7.5 \mathrm{~mm}$.; ceph., $3.5 \mathrm{~mm}$.; abd., $4.0 \mathrm{~mm}$.; width of abd., $2.6 \mathrm{~mm}$.

Cephalothorax golden brown, covered with fine white hairs and long scattered black hairs, widest between second and third pair of legs, much narrowed anteriorly, gently rounded, thoracic groove distinct; eyes, anterior row slightly recurved, a.m.e. largest of the eight, separated by a radius and almost touching a.l.e., posterior row procurved so that anterior margin of p.m.e. and middle of p.l.e. form a straight line, p.m.e. slightly angulate rather than oval, separated by a little more than their long diameter and by a little less from p.l.e., lateral eyes subequal and separated by less than a diameter; quadrangle of median eyes wider in front and slightly higher than wide; clypeus about one-half diameter of a.m.e.; mandibles vertical, cone shaped, brown covered with long black hairs, fang groove short, inferior margin with no teeth, superior margin with very small nodules, fang short; labium almost twice as high as wide, lateral margins at basal third slightly excavate; maxillæ not twice as high as labium, only slightly impressed, slightly inclined over labium, upper margins rounded; sternum oval, slightly narrowed between first coxæ, lateral margins slightly emarginate, tip obtusely pointed in front of fourth coxæ; abdomen dark gray with a median light stripe, wide at base, sides converging and almost meeting at middle and 
continuing on posterior half as a much narrower spot that does not reach tip; venter light gray; legs, left III missing, 4-1-2-3, same color as cephalothorax, thinly covered with fine dark hairs, anterior metatarsi and tarsi with dense scopula, spines, I tibia, I-I-I, basal, median and apical, left tibia with basal spine missing, metatarsus, 2 basal, II tibia, I-I, median and apical, spines more numerous on posterior pairs, III tibia, dorsal, I basal spine, IV tibia dorsal, $\mathrm{O}$ spine; epigynum, the openings a short distance above the fold, connected with fold by a heavily chitinized groove, above are the round receptacles separated by half a diameter.

Holotype \& Florida; Sebastian, February, 1932, (G. Nelson).

This species differs from others found in Florida by the procurved row of posterior eyes, quadrangles of median eyes wider in front, and the lack of dorsal spine on the IV tibia. Herpyllus cratus Chamb., also from Florida, is immature and so is difficult to place. It is much darker in color, possibly due to the length of time it has been in alcohol, it is larger, the spines on the anterior tibiæ are not paired, the epigynum while showing the chitinized grooves will be evidently much longer, but it has a dorsal spine at the base of III tibia and none at the base of IV tibia.

\section{CLUBIONIDAE}

Clubiona transversa sp. nov.

Fig. 8

Female. Length, $8.6 \mathrm{~mm}$.; ceph., $3.1 \mathrm{~mm}$.; abd., $5.5 \mathrm{~mm}$.

Cephalothorax pale yellow shading to brown near the eyes, sides almost parallel, front broad, thoracic groove distinct; eyes, anterior row straight, eyes subequal and equidistant, separated by less than a diameter, posterior row longer than anterior, covering almost entire width of head, straight or very slightly procurved, eyes subequal p.m.e. slightly nearer p.l.e. than to each other; quadrangle of median eyes narrower in front and wider behind than high; clypeus less than a radius of a.m.e.; mandibles very 
dark brown, swollen at base, long, boss small, fang groove slightly oblique, superior margin with one large tooth, preceded by several small teeth and followed by one medium sized tooth, inferior margin with two teeth, fang, stout and evenly curved; labium twice as high as wide, lateral margins excavate on basal third, tip slightly narrower than base; maxillæ twice as high as labium, tips slightly dilate; palpus inserted at basal third; sternum twice as long as wide, width of labium in front and pointed in front of IV coxæ; abdomen oval, twice as long as wide, pointed above spinnerets, a dirty white shading to a light brown at tip, venter pale with a faint dusky median line; legs, 4-1-2-3, right I and IV missing, pale dense scopula on anterior tarsi and metatarsi, faint scopula on distal half of anterior tibiæ, spines, I and II tibiæ, 2-2, long ventral, O lateral, metatarsi 2, basal, ventral, O lateral; epigynum wider than high, convex, with a dark narrow median septum which starts from a heavily chitinized ridge and curls under the fold midway in the clear area each side, starting from the median septum is a narrow dark transverse bar which does not reach outer margin, openings probably near the ends of the chitinized ridge.

Holotype $\&$ Texas; Dallas, White Rock Lake, 25 March, 1935. (S. Jones).

\section{Wulfila immaculata Banks}

Fig. 1

Bull. Amer. Mus. Nat. Hist., 1914, 33, p. 640, pl. 43, fig. 7.

Male. Length, $4.0 \mathrm{~mm}$; ceph., $1.5 \mathrm{~mm}$; abd., $2.2 \mathrm{~mm}$. (measurement of length is without mandibles and spinnerets).

Cephalothorax almost white, sparsely covered with colorless hairs, not very high, sides evenly rounded, thoracic groove a depression rather than a groove, at anterior outer corner is a darkened vertical cusp or spur similar to figure of $W$. tropica Petrunkevitch Trans. Conn. Acad., 1930, 31, p. 68, figs. 56 to 60 ; eyes, very little black pigment about eyes, anterior row slightly recurved, a.m.e. smallest of eight, separated by a scant diameter and from a.l.e. by 
more than a diameter, posterior row longer than anterior, procurved, eyes equidistant and subequal; quadrangle of median eyes narrower in front and as high as wide; clypeus one and a half diameters of a.m.e.; mandibles three-fifths as long as cephalothorax antenuate, outer margins parallel, fang groove long, oblique, superior margin with a distinct carina from base of fang ending in five teeth which extend on median margin, inferior margin illy defined and impossible to see any teeth; Petrunkevitch in redescribing the female $W$. immaculata states, Trans. Conn. Acad., 1930, 31, p. 85, that the mandible when stained and mounted on a slide shows a row of nine small teeth, very scant scopula on superior margin only, fang long and sinuous; labium higher than wide; maxillæ twice as long as labium, tips slightly widened, palpi inserted at basal third; sternum flat, oval, IV coxæ separated by a diameter; abdomen oval, more than twice as long as wide, colorless, spinnerets extending beyond tip, openings of tracheal spirale about middle; legs, I pair much the longest, fem., $3.0 \mathrm{~mm}$.; pat. + tib., $4.6 \mathrm{~mm}$.; metat., $4.1 \mathrm{~mm}$.; tar., $2.0 \mathrm{~mm} .=13.7$ mm. Spines colorless, femur, 3 dorsal serial, tibia, 2-2, ventral, 2 lateral, metatarsus, 2, basal, 2 lateral, spines more numerous on posterior legs; palpus, longer than cephalothorax, tibia longer than patella, but little over half as long a terminal joint, tibial apophysis a small abrupt cusp at right angles from the joint with three short spines on ventral side and several long bristles on exterior.

Allotype ô Florida; Bicknell's Hammock, 30 April, 1935 (Gribbins).

The type, a female from Vinales, Cuba, is in the American Museum of Natural History. It has been found since at Porto Rico and Mona. A female was taken at Siboney, Cuba, without the first pair of legs. Petrunkevitch gives a detailed description of the type female in Trans. Conn. Acad., 1930 , p. 85, fig. 72. The male agrees with the female with the long first legs, the eyes, teeth on the mandibles and number of spines on the legs. The spines are difficult to see. It does not agree with the definition of the genus given by Petrunkevitch, 1930, p. 66, but probably 
when both sexes of all species are known, the difference in the number of spines will be modified. The cusps on the outer corners of the cephalothorax are evidently a secondary sexual character.

\section{EXPLANATION OF PLATE III}

Fig. 1. Wulfila immaculata Banks

Fig. 2. Schizocosa perplexa sp. n.

Fig. 3. Nodocion agilis sp, n.

Fig. 4. Drassyllus pullus sp. n.

Fig. 5. Drassyllus pullus sp. n.

Fig. 6. Herpyllus faxoni sp. n.

Fig. 7. Oxyopes helius Chamb.

Fig. 8. Clubiona transversa sp. n.

Fig. 9. Tegenaria simplex sp. n. 
Psyche, 1936

Vol. 43, Plate III

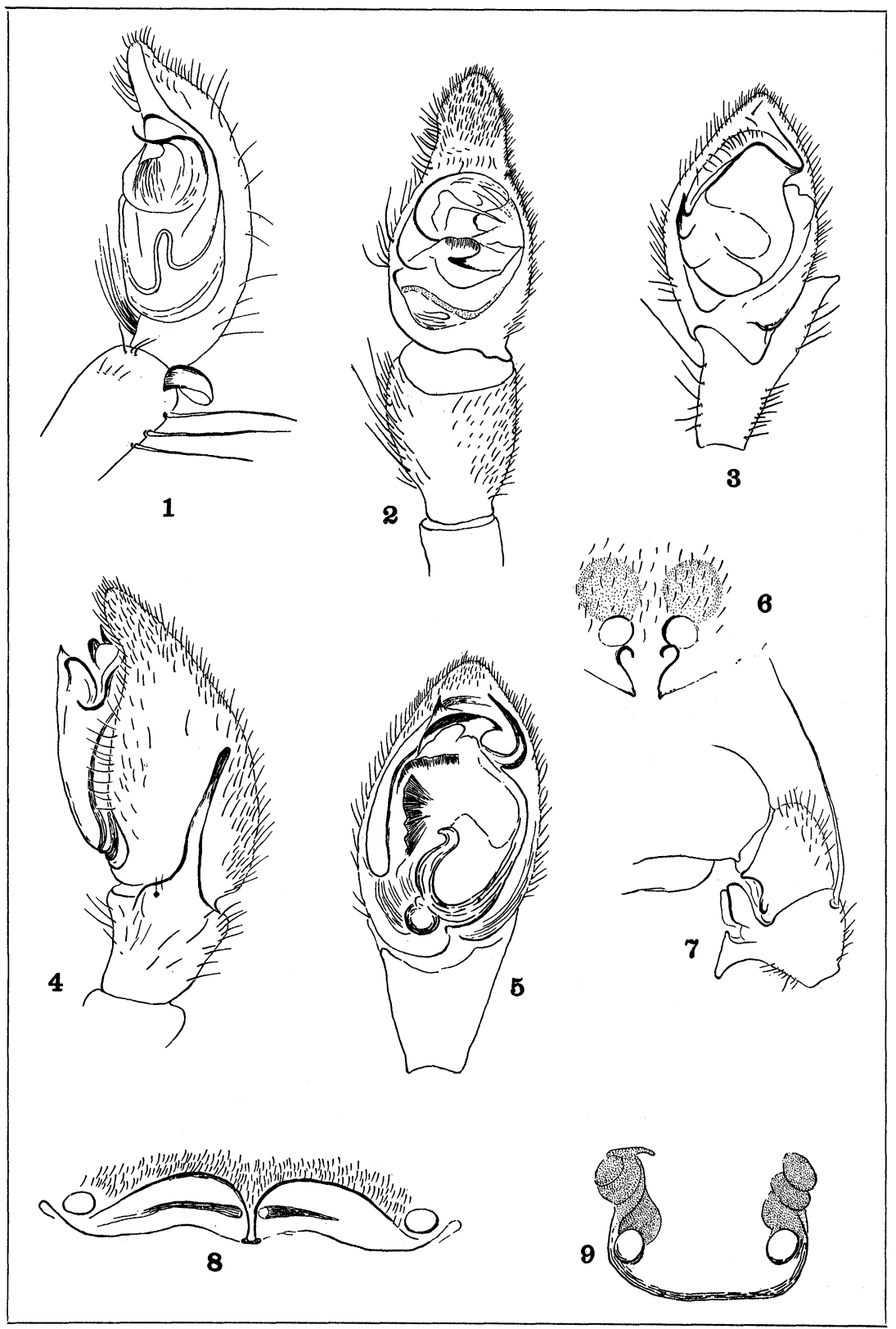

Bryant-New Southern Spiders 

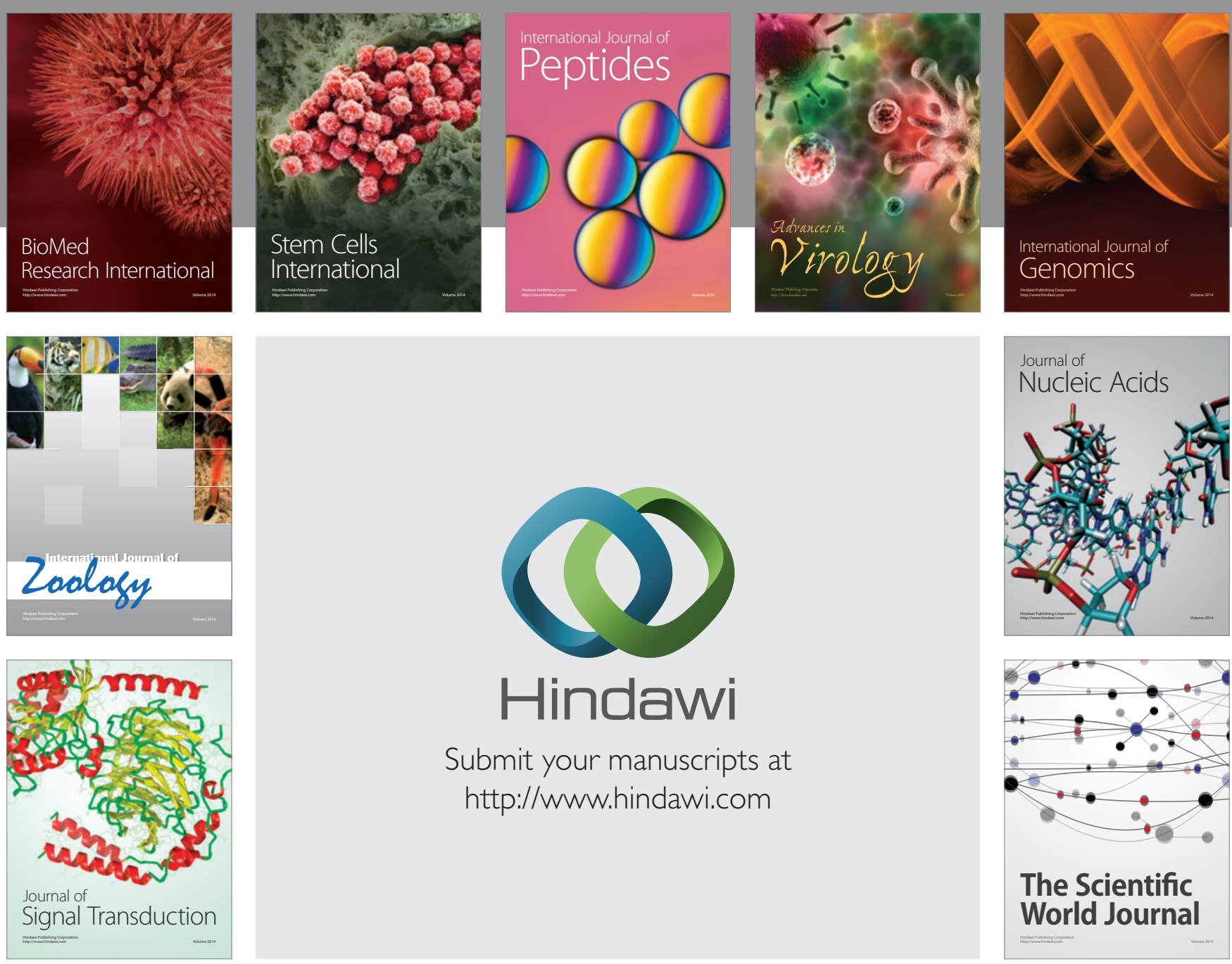

Submit your manuscripts at

http://www.hindawi.com
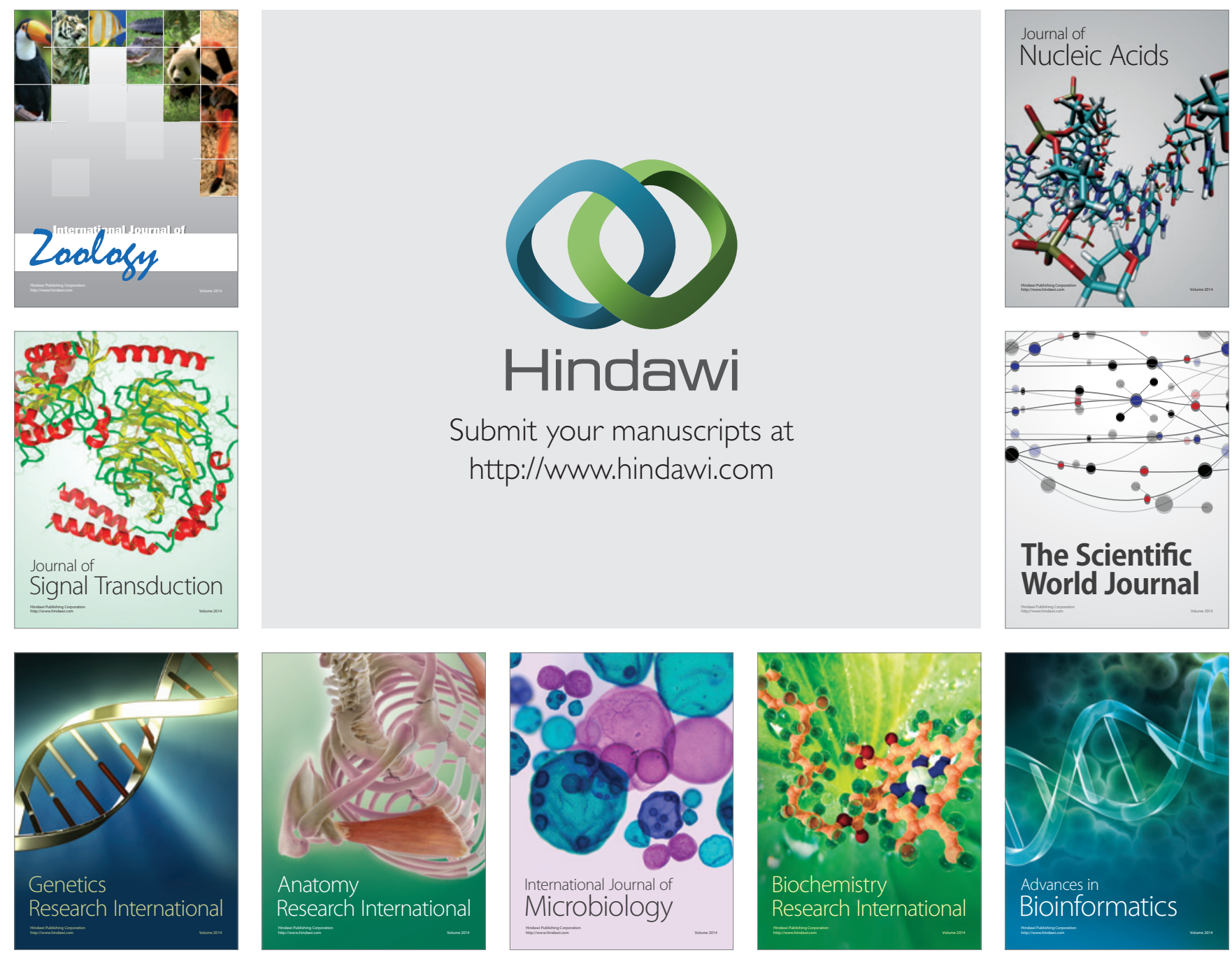

The Scientific World Journal
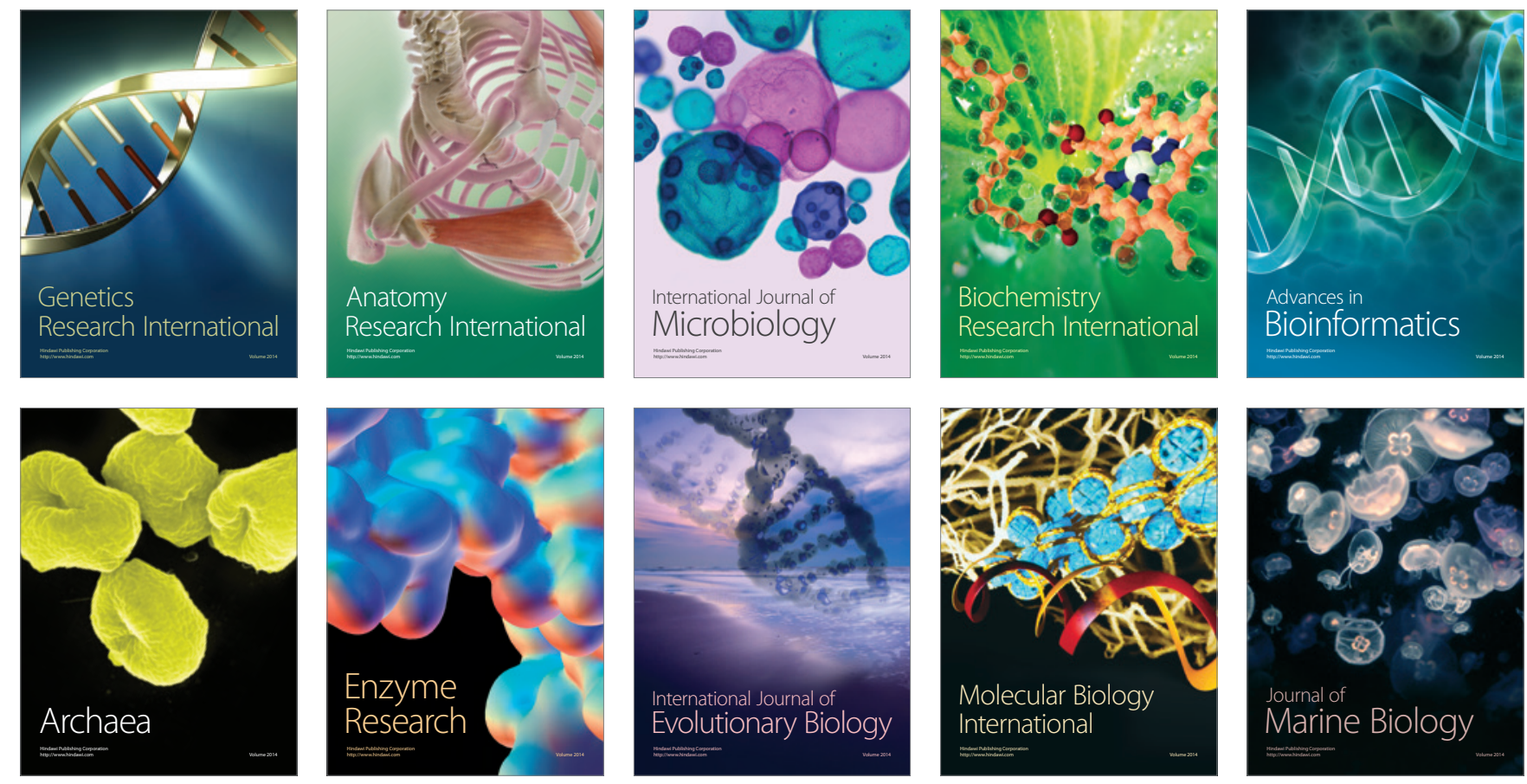